\title{
Concrete performance evaluation of coarse aggregate replacement by civil construction waste
}

\author{
Juliane Patricia de Oliveira1 \\ Carlos Henrique dos Santos2 \\ Maria Lúcia Okumura3 \\ Natália Ueda Yamaguchi4
}

\begin{abstract}
The construction sector is considered a major generator of environmental impacts due to the high consumption of natural resources and waste generation. Thus, this article aims to evaluate the performance of concrete produced by the partial and total replacement of natural coarse aggregate by recycled coarse aggregate, derived from the concrete residue of buildings and demolitions. The study was carried out by comparing the compressive strength and water absorption of three different concrete mix concentrations, keeping the water/cement factor of 0.60 and changing only the proportions of recycled coarse aggregate between $0 \%, 50 \%$, and $100 \%$. The results showed that the higher the percentage of substitution, the greater the water absorption and the lower the resistance results for concrete compression. This result was obtained due to the lighter characteristic of the recycled aggregate compared to the natural aggregate. It was concluded that the concrete produced with recycled aggregates could be used in nonstructural functions, giving an adequate destination to the construction and demolition waste and consequently reducing the extraction and consumption of natural resources and contributing for the sustainable development.
\end{abstract}

Keywords: Green concrete. Recycled aggregates. Recycled aggregate concrete

IEngenheira civil, Centro de Ciências Exatas, Tecnológicas e Agrárias, Universidade Cesumar, Maringá, PR, Brasil Email: julianepdeoliveira@outlook.com

IIEngenheiro civil, Centro de Ciências Exatas, Tecnológicas e Agrárias, Universidade Cesumar, Maringá, PR, Brasil Email: carlos.henrique@unicesumar.edu.br

IIIMestranda em Tecnologias Limpas, Universidade Cesumar, Instituto Cesumar de Ciência, Tecnologia e Inovação, Maringá, PR, Brasil Email: marialucia.okumura@outlook.com

IVProfessora Doutora, Mestrado em Tecnologias Limpas, Universidade Cesumar, Instituto Cesumar de Ciência, Tecnologia e Inovação,Maringá, PR, Brasil Email: nataliaueda@hotmail.com 


\section{Highlights}

-Concrete was produced with 50 and $100 \%$ of coarse aggregate replacement.

-The produced concrete presented greater water absorption and lower compression resistance compared to the concrete reference.

-The green concrete could be used for nonstructural purposes.

\section{Graphical abstract}

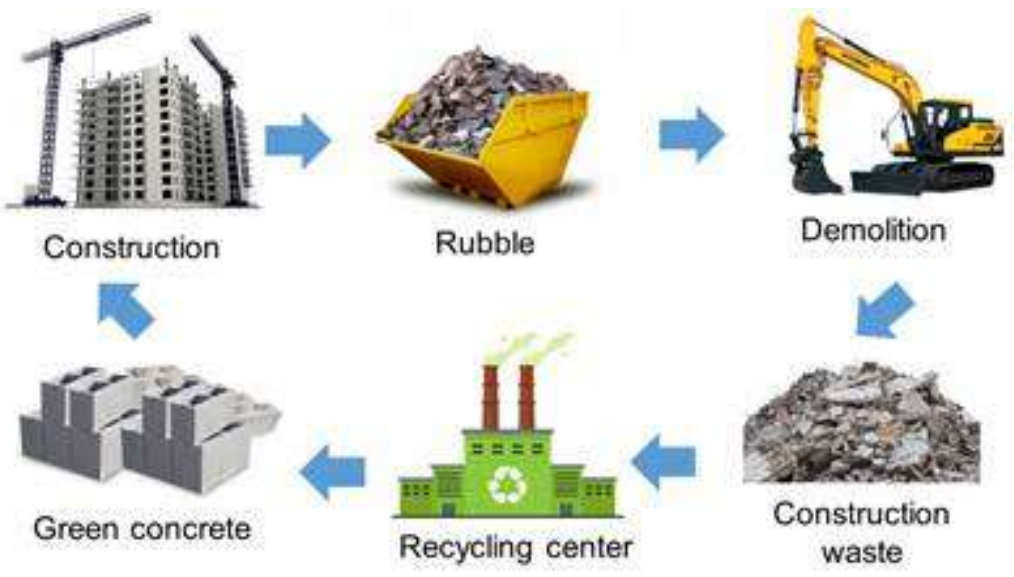

\section{Introduction}

Population growth has caused an increase in waste deposited in the environment, generating greater offers and demands for products, making prices more accessible and consequently improving the population's purchasing power. This creates a growing vicious circle of continuous consumption, sales, and production (BARBOSA; IBRAHIN, 2014)

Civil construction is considered one of the most important economic activities, directly reflecting on the economic and social development of the country, but it is also known as a major generator of environmental impacts, both for the high production of waste, as well as for the use of natural resources and landscape modification. The sector has the difficult task of reconciling a productive activity of this relevance with actions that generate responsible sustainable development while reducing environmental impacts (PINTO, 2005). 
The construction industry handles a large amount of construction materials in its activities, consequently producing a high volume of waste, which is irregularly deposited in easily accessible places, such as vacant lots (PASCHOALIN FILHO; STOROPOLI; DUARTE, 2014).

In 2017, about 71.6 million tons of urban solid waste was collected in Brazil, registering a collection coverage index of $91.2 \%$ for the country, which shows that 6.9 million tons of waste were not collected and, consequently, had an improper destination. Of these 71.6 million tons collected, 45 million (62\%) is civil construction waste (CCW) (ABRELPE, 2017).

The large generation of waste is not the only problem combined with civil construction; the aggregates used in this sector are the most consumed mineral inputs in the world. The basic product of the construction industry, the Portland cement concrete, is composed, on average, by $42 \%$ coarse aggregate, $40 \%$ sand, $10 \%$ cement, $7 \%$ water and $1 \%$ chemical additives for every cubic meter. Concrete is the second most consumed material by humanity, as a consequence of the high consumption, we have the environmental impacts generated by the exploration of mineral deposits (FRANCISCO; HADDAD, 2002).

The CCW recycling sector is a developed market in European countries due to the scarcity of natural resources, however, Brazil is still incipient when it comes to this issue. In order to spread this practice, the country must engage with environmental and preservationist issues. Sustainability ensures higher than expected growth, facilitating negotiations with public, private and potential partners (ABRECON, 2019).

Due to environmental concerns regarding the destination and management of the CCW associated with the large use of concrete, one of the alternatives is the reuse of CCW as recycled aggregate in the manufacture of non-structural concrete. This type of concrete consists of a much smaller percentage of cement and mineral components, as well as eliminating the use of additives or fibers, and is widely used in the construction sector with its mechanical properties and durability less demanding than for concrete for structural purposes (JUAN-VALDÉS et al., 2018).

However, with the objective of reconciling the civil construction sector to sustainable development, this study evaluated the replacement of natural aggregate with recycled 
aggregate (concrete) from civil construction itself. The compressive strength and absorption of the concrete prepared with these residues were tested, with the aim of contributing to the reuse of materials and, consequently, reducing the amounts of mineral resources explored and extracted from nature.

\section{Material and methods}

\subsection{Materials}

Commercial regional Portland cement, sand and natural coarse aggregate of $19 \mathrm{~mm}$, Fig1(a), were used for the execution of the mixtures and concrete production. The recycled coarse aggregate, Fig1(b), was collected in a company that provides services collecting, sorting and crushing construction and demolition waste, classified as class A waste, according to Resolution 307 (CONAMA, 2002), which is the reusable or recyclable waste as aggregate.

Figure $1-(a)$ Natural and (b) recycled coarse aggregate

(A)

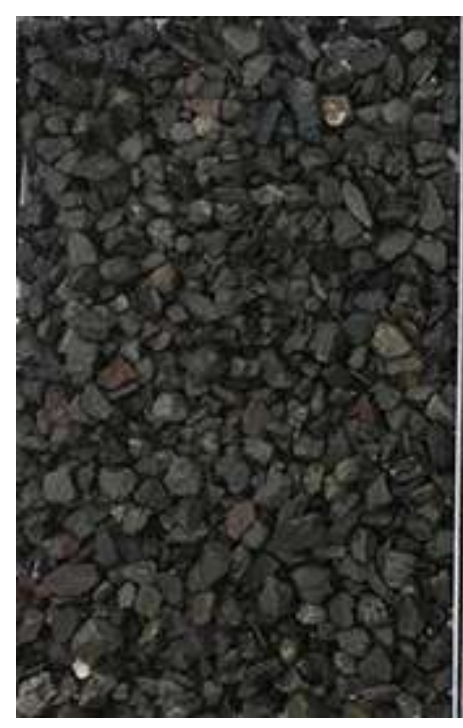

(B)

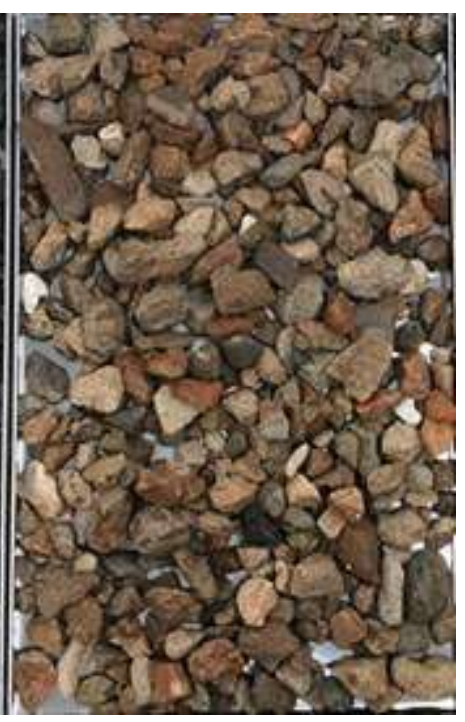

Source: Authors (2019). 
To check the granulometry of coarse aggregates, the set of sieves with openings of the normal series NBR NM 248 (ABNT, 2003) was used. Particle size curve of the natural coarse aggregate and recycled coarse aggregate are shown in Figure 2.

Figure 2 - Particle size curves of natural and recycled gravel.

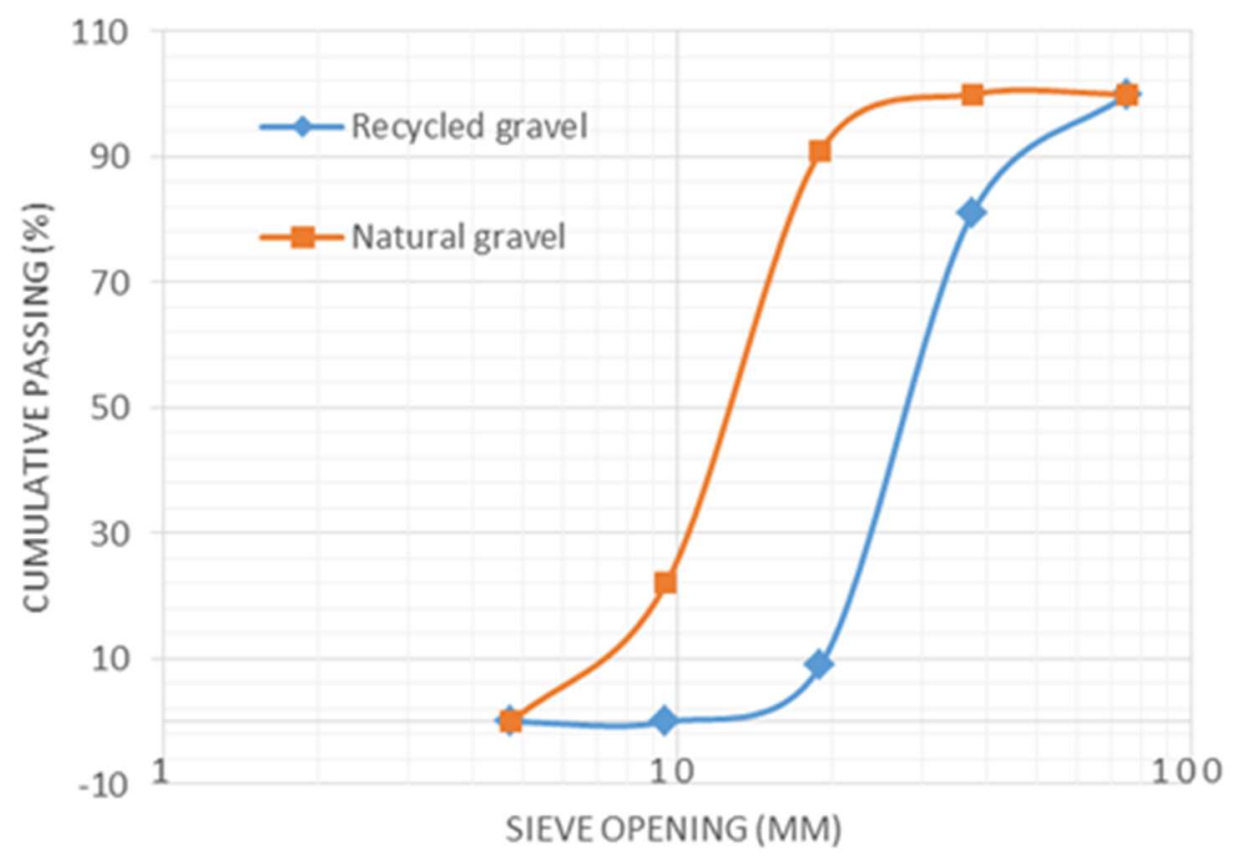

Fonte: Authors (2019).

The physical properties of the coarse aggregate were measured using NBR NM 53 (ABNT, 2009a), for the determination of apparent specific mass and water absorption. The tests were performed on the recycled coarse aggregate and the natural coarse aggregate (Table 1). These results are essential since they present the absorption rates, defining the need to moisten the aggregates, or not, before adding them to the concrete mixer, thus avoiding part of the water calculated for the mixing being absorbed by the aggregates, which can cause problems in the hydration of the concrete.

(Continue...) 
Table 1 - Characteristics of coarse aggregates used in this study

\begin{tabular}{|c|c|c|}
\hline Coarse aggregate & $\begin{array}{l}\text { Specific mass of dry } \\
\text { coarse }\left(\mathrm{kg} / \mathrm{dm}^{3}\right)\end{array}$ & Absorption (\%) \\
\hline Natural & 2.60 & 4.50 \\
\hline Recycled & 2.07 & 6.97 \\
\hline
\end{tabular}

\subsection{Concrete preparation}

Three different concrete were prepared, CNA (concrete without replacing the natural aggregate), CR50 (recycled concrete with 50\% replacement of the natural aggregate), and CR100 (recycled concrete with 100\% replacement of the natural aggregate). In order for the compressive strength and water absorption of the samples to be measured, the same watercement factor was used in all mixes, as recommended by NBR 5738 (ABNT, 2016) for generaluse nonstructural concrete. The cement and natural fine aggregate used had the same specifications for all samples and the natural coarse aggregate used was the same in the samples of $0 \%$ and $50 \%$. No chemical additives were added to the mix. All samples were produced on the same day, thus avoiding possible differences due to the climate and materials used. In total, 36 samples were produced (Table 2).

Table 2 - Number of prepared samples per test.

\begin{tabular}{|c|c|c|c|c|}
\hline \multirow{3}{*}{ Type of sample } & \multicolumn{4}{|c|}{ Number of prepared samples } \\
\hline & \multicolumn{3}{|c|}{ Resistance test (MPa) } & \multirow{2}{*}{$\begin{array}{c}\text { Absorption } \\
\text { test (\%) }\end{array}$} \\
\hline & 7 days & 14 days & 28 days & \\
\hline CNA & 3 & 3 & 3 & 3 \\
\hline CR50 & 3 & 3 & 3 & 3 \\
\hline CR100 & 3 & 3 & 3 & 3 \\
\hline
\end{tabular}


After the characterization and definition of the materials to be used, the preparation of the previously defined concretes started. The method used for making the mix was IPT/EPUSP (Technological Research Institute/ USP Polytechnic School), preparing based on NBR NM 33/1998 (ABNT, 1998), fixing the slump test according to NBR 5738 (ABNT, 2015) between 10 and $16 \mathrm{~cm}$.

As the specific mass of the recycled coarse aggregate is smaller than the natural coarse aggregate, compensation was made according to Equation 1.

$M_{R A}=M_{N A} \cdot\left(\gamma_{R A} / \gamma_{N A}\right)$

Where: $M_{R A}=$ mass of recycled aggregate, $M_{N A}=$ mass of natural aggregate, $\gamma_{R A}=$ specific mass of recycled aggregate and $\gamma_{\mathrm{NA}}=$ specific mass of natural aggregate.

After calculating the compensations for all mixes, the amount of water to be added to the recycled coarse aggregate was defined to moisten it before addition to the mixer. According to NBR 15116 (ABNT, 2004), pre-wetting around 80\% of the absorption content is recommended. However, as the absorption percentages between the natural and recycled aggregates did not present much difference, only $50 \%$ of the absorption content was adopted. The recycled coarse aggregate was moistened 10 minutes before mixing in the concrete mixer.

After the definitions, all materials were weighed according to the initial mix proportions of 1: 2.24: 2.76, mortar content of 0.54 and water-cement factor of 0.60 , and later added to the mixer in the following sequence, $80 \%$ water, $100 \%$ coarse aggregate, $100 \%$ cement, $100 \%$ fine aggregate and $20 \%$ water, mixing for a few minutes. The three concretes were prepared using the same quantities, obtaining the desired cone appearance and slump test. The mixture was deposited in $10 \times 20 \mathrm{~cm}$ cylindrical molds. Subsequently, the sample were exposed to room temperature and humidity for $24 \mathrm{~h}$, then they were demolded and washed for wet curing, where they remained until the tests of resistance to compression and absorption by immersion were conducted. 


\subsection{Concrete performance evaluation}

The performance of concrete produced by partially and totally replacing the natural coarse aggregate with the coarse aggregate from the recycling of concrete in construction or demolition work was evaluated through tests of resistance to compression and water absorption by immersion.

The compressive strength test was performed on an electric hydraulic press (Solotest, Brazil) with a capacity of up to $100 \mathrm{Tf}$, digital electronic indicator, $220 \mathrm{~V}-50 \mathrm{~Hz}$ with peak memory and pump, following the methods and presenting the results according to NBR 5739 (ABNT, 2018). The samples were ruptured with a curing age of 7, 14 and 28 days.

Each sample was carefully prepared, capped with neoprene rubber, and positioned in the press, starting the rupture process, with loading applied continuously, until its rupture.

The immersion water absorption test was carried out according to NBR 9778 (ABNT, 2009b). All samples were weighed and taken to the oven where they remained for $72 \mathrm{~h}$ at a temperature of $105 \pm 5{ }^{\circ} \mathrm{C}$, obtaining a constancy in the mass up to $0.5 \%$. After cooling to room temperature, the mass of each sample was recorded. Subsequently, the material was kept immersed in water for another $72 \mathrm{~h}$, removed and weighed to obtain the saturated specific mass. Finally, the samples were weighed immersed in water to obtain the saturated mass immersed in water.

\section{Results and discussion}

The results obtained for compressive strength are shown in Figure 3 and the results of the immersion absorption test are shown in Table 3. 
(Continue...)

Figure 3 - Axial compressive strength test results with 7, 14 and 28 curing days.

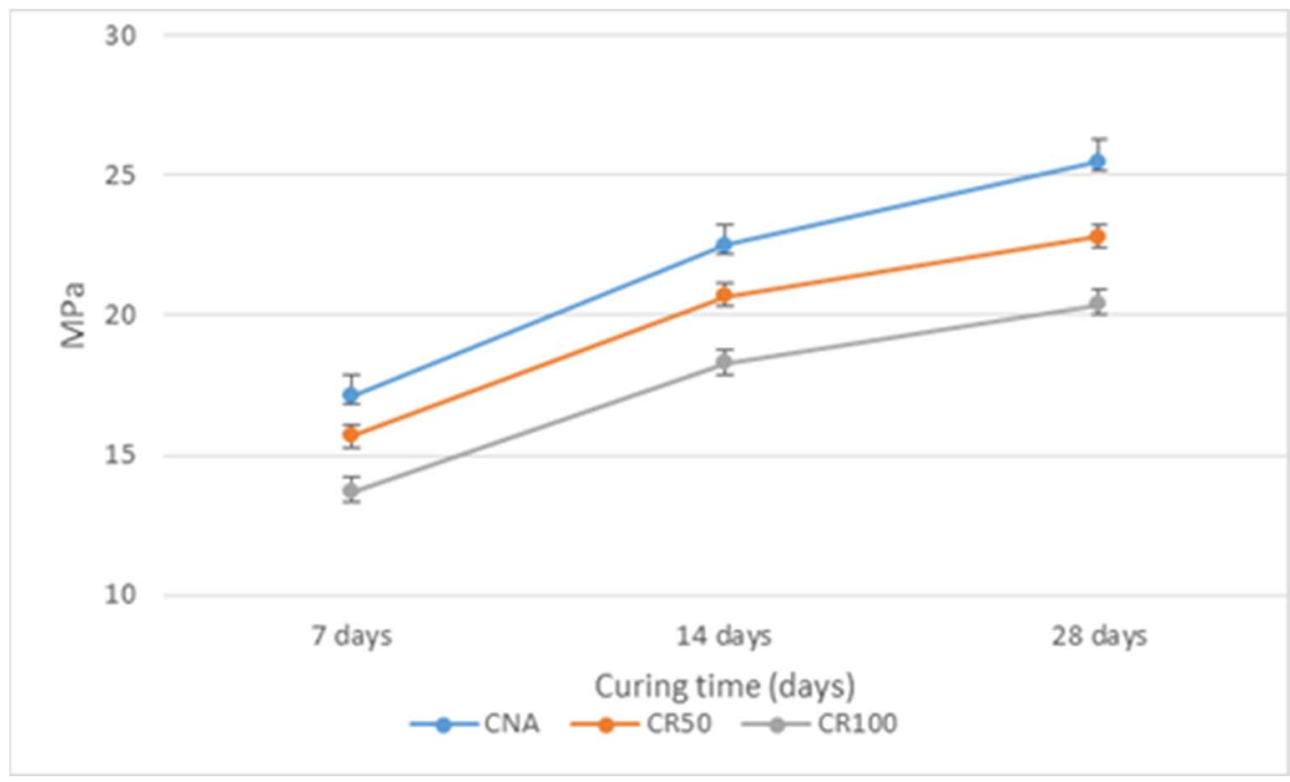

Fonte: Authors (2019).

Table 3 - Results of the test of water absorption by immersion

\begin{tabular}{|c|c|c|c|}
\hline Sample & $\begin{array}{c}\text { Absorption } \\
(\%)\end{array}$ & $\begin{array}{c}\text { Void index } \\
\text { (\%) }\end{array}$ & $\begin{array}{c}\text { Specific mass } \\
(\%)\end{array}$ \\
\hline CNA & 8.01 & 17.51 & 2.64 \\
\hline CR50 & 8.79 & 17.53 & 2.42 \\
\hline CR100 & 9.19 & 17.89 & 2.37 \\
\hline
\end{tabular}

With the results of the analysis of compressive strength and water absorption by immersion, we can compare and discuss the values for each sample with different percentages of recycled coarse aggregate.

It can be seen from Table 3 that the CNA has a superior compressive strength to the samples with the recycled aggregate (CR50, CR100) for all curing ages (7, 14 and 28 days). It also presents a lower absorption percentage, lower void index percentage and higher real 
specific mass, when compared to the green concrete. In fact, the higher the natural coarse replacement the worse the compressive strength, absorption and void index percentages.

A possible justification for the inferior results would be the nature and characteristic of the recycled coarse aggregate, they are heterogeneous materials, that is, of an uneven nature and composed of different elements, they also have a higher porosity compared to natural waste, resulting in greater porosity in concrete and as a consequence, a lower capacity with reduced compressive strength. This material becomes harmful to structural elements, which due to its pores, reduces the ability to prevent corrosion in the armatures (TAVARES; KAZMIERCZAK, 2016).

Other factors that interfere with the performance of both fresh and hardened concrete are the granulometry of coarse aggregates and the workability, density, quality, void index and other factors, which are all influenced by the grain size distribution. The wellgraded aggregate is the one that presents a smoother curve, reducing the consumption of binders and having a lower void index, since its empty spaces are occupied by smaller grains, therefore, the better the grains are distributed, the higher the quality of the aggregate and, consequently, the higher the quality of the final material (HAGEMANN; KLAWITTER, 2012). The granulometric curves of the aggregates used (Figure 1), both natural and recycled, were not smooth, having characteristics of a discontinuous material, justifying the percentage of voids shown in the immersion absorption results.

The results of water absorption, void index and real specific mass follow the characteristics of the recycled aggregate; as it showed superior absorption than the natural aggregate, the concrete produced with the recycled coarse aggregate showed greater absorption to the CNA, in the same way it happens with the voids index and specific mass. A similar result was found by Cabral et al. (2009), due to the characteristics of the recycled coarse aggregate, the strength and absorption of the final material were affected. The higher the percentage of recycled coarse aggregate is used, the lower are the results of compressive strength and greater the water absorption of concrete.

In the analysis of concrete in the fresh state, the question of workability stands out where the greater the degree of substitution with recycled aggregate, the greater the abatement and, consequently, there will be variations in the abatements, making the analysis 
difficult. In order to fix the slump test while maintaining the level of workability, it is necessary to use a superplasticizer additive to the concrete mixture. The necessity of the superplasticizer additive is due to the granulometry of the recycled aggregates, where the higher concentration of recycled aggregates the greater the absorption of mixing water (ARAÚJO et al., 2016). It was also observed that the higher the content of recycled aggregate, the lower the resistance to compression. Consequently, the modulus of elasticity decreases compared to the CNA, this occurs due to the increased shrinkage by drying hydraulics (EGUCHI et al., 2007).

\section{Conclusion}

With the results of the studies carried out, it was concluded that the substitution of the natural coarse aggregate for the recycled coarse aggregate affects the compressive strength and also the water absorption by immersion of the concrete. The higher the percentage of substitution, the greater the absorption results and the lower the resistance results concrete compression. The construction waste usually has an unknown origin, and maybe made of a more or less resistant material, irregularly shaped and have greater porosity, which affects the final performance of the concrete. However, the recycled aggregate presents itself as being a lighter aggregate, producing a final material with that same characteristics. Even with the inferior performance, the residues can be used for the production of concretes without a structural function, replacing $100 \%$ of the natural aggregate or associating with other residual materials such as steel fibers and, thus, reducing the use of the natural aggregate for structural purposes, having a positive final destination for the environment, reducing residues and exploitation of natural resources.

\section{Acknowledgements}

Thanks to Instituto Cesumar de Ciência, Tecnologia e Inovação (ICETI-Brazil) for supporting this project.

\section{References}


12

ABNT. NBR NM 248 - Agregados - Determinação da composição granulométrica. Brazil 2003.

ABNT. NBR 15116:2004 - Agregados reciclados de resíduos sólidos da construção civil Utilização em pavimentação e preparo de concreto sem função estrutural - Requisitos.

ABNT. NBR NM 53:2009 - Agregado graúdo - Determinação da massa específica, massa específica aparente e absorção de água.

ABNT. NBR 9778:2005 Versão Corrigida 2:2009. Argamassa e concreto endurecidos Determinação da absorção de água, índice de vazios e massa específica.

ABNT. NBR 5738: Concreto - Procedimento para moldagem e cura de corpos de prova. Associação Brasileira de Normas Técnicas, p. 9, 2015. Disponível em: https://doi.org/01.080.10; 13.220.99

ABNT. NBR 5739 - Concreto - Ensaio de compressão de corpos de prova cilíndricos. Brazil 2018.

ABNT, A. B. D. N. T. ABNT NBR NM 33: Concreto - Amostragem de concreto fresco. ABNT, A. B. D. N. T. NBR NM 33: Concreto - Amostragem de concreto fresco. p. 5, 1998., p. 5, 1998.

ABRECON. Mercado. 2019.

ABRELPE. Panorama dos resíduos sólidos no Brasil 2017. 2017.

ARAÚJO, D. D. L. et al. Influência de Agregados Reciclados de Resíduos de Construção nas Propriedades Mecânicas do Concreto. REEC - Resvista Eletrônoca de Engenharia Civil, p. Volumme 11, N 1, 16-34, 2016. Disponível em: https://resista.ufg.br/index.php/reec/index

BARBOSA, R. P.; IBRAHIN, F. I. D. Resíduos sólidos: impactos, manejo e gestão ambiental. São Paulo: Editora Érica, 2014.

CABRAL, A. E. B. et al. Desempenho de concretos com agregados reciclados de cerâmica vermelha. Cerâmica, v. 55, n. 336, p. 448-460, 2009. Disponível em: https://doi.org/10.1590/S0366-69132009000400016

CONAMA. RESOLUÇÃO N 307 - Estabelece diretrizes, critérios e procedimentos para a gestão dos resíduos da construção civil. : Publicação DOU nº 136, de 17/07/2002, págs. 9596, 2002.

EGUCHI, K. et al. Application of recycled coarse aggregate by mixture to concrete construction. Construction and Building Materials, v. 21, n. 7, p. 1542-1551, 2007. Disponível em: https://doi.org/10.1016/j.conbuildmat.2005.12.023

FRANCISCO, B. C.; HADDAD, A. N. Gestão de contratos na construção civil. Revista Vértices, São Paulo, v. 4, n. 1, p. 17-23, 2002. Disponível em: https://doi.org/10.5935/18092667.20020003 
HAGEMANN, M.; KLAWITTER, D. Discretisation of light-weight concrete elements. In: (H. S. Muller, M. Haist, F. Acosta, Org.) 2012, Karlsruhe. Proceedings of The 9th fib International PhD Symphosium in Civil Engineering. Karlsruhe: KIT Scientific Publishing, 2012. p. 269-274.

JUAN-VALDÉS, A. et al. Mechanical and microstructural characterization of non-structural precast concrete made with recycled mixed ceramic aggregates from construction and demolition wastes. Journal of Cleaner Production, v. 180, p. 482-493, 2018. Disponível em: https://doi.org/10.1016/j.jclepro.2018.01.191

PASCHOALIN FILHO, J. A.; STOROPOLI, J. H.; DUARTE, E. B. L. Viabilidade Econômica da Utilização de Resíduos de Demolição Reciclados na Execução do Contrapiso de um Edifício Localizado na Zona Leste da cidade de São Paulo. Revista Eletrônica em Gestão, Educação e Tecnologia Ambiental - REGET, v. 18, n. 2, p. 928-943, 2014. Disponível em: https://doi.org/10.5902/2236117013750

PINTO, T. de P. Gestão Ambiental de Resíduos da Construção Civil: A experiência do SindusCon-SP. Obra Limpa, p. 1-48, 2005. Disponível em: https://doi.org/10.1080/09640568.2010.490058

TAVARES, L. M.; KAZMIERCZAK, C. S. The influence of recycled concrete aggregates in pervious concrete. Revista IBRACON de Estruturas e Materiais, v. 9, p. 75-89, 2016. 